\title{
Human Decidua Is a Major Source of Renin
}

Kathryn J. Shaw, Yung S. Do, Siri Kjos, Pam W. Anderson, Tatsuo Shinagawa, Louis Dubeau, and Willa A. Hsueh

Departments of Medicine, Obstetrics, and Gynecology, and Pathology, University of Southern California, School of Medicine, and the University of Southern California Comprehensive Cancer Center, Los Angeles, California 90033

\begin{abstract}
Plasma prorenin levels are elevated in normal pregnant women. Current evidence suggests renin production by tissues of the uteroplacental unit contribute to this elevation. The purpose of this investigation was to define the source of renin biosynthesis within the human uteroplacental unit and to characterize the renin produced. RNA extraction and Northern blot analysis consistently demonstrated renin mRNA expression in uterine lining both in the pregnant (decidua) and nonpregnant states (endometrium) and in fetal chorion laeve, which is inseparable from the decidua. In contrast, renin mRNA expression was not detected in basal plate and intertwin chorion (which is separate from decidua), amnion, myometrium, or placental villae. The total renin content in decidual homogenates was twoto threefold greater than in endometrial homogenates, and cultured human decidual cells produced significantly more total renin than cultured human endometrial cells, suggesting that pregnancy enhanced renin production by the cells lining the uterus. Immunoblot analysis and $\left.{ }^{3} \mathbf{H}\right]$ leucine incorporation identified $47,000-\mathrm{mol}$ wt prorenin as the major form of renin produced by cultured human decidual cells. These studies indicate that maternal decidua is the major source of prorenin in the uteroplacental unit.
\end{abstract}

\section{Introduction}

In normal human pregnancy circulating prorenin levels are profoundly elevated compared with levels in the nonpregnant state $(1,2)$. Early in pregnancy the ovary appears to be responsible for the increase in plasma prorenin concentration $(3,4)$, while the uterine-fetal-placental unit may contribute in part to the prorenin rise in the third trimester (5). The exact source of uteroplacental prorenin is unknown. Fetal chorion laeve has been thought to be the major source (6). However, chorion laeve abuts against maternal decidua, which forms the inner lining of the uterus in pregnancy, so that decidua is also obtained when chorion tissue or cells are isolated. Early studies have suggested that decidua contains and secretes an enzyme with reninlike activity that is enhanced after trypsin treatment (7). Thus, studies of chorion renin production have been complicated by potential contributions from maternal decidua. In addition, when renin activity of tissue homogenates and per-

Address correspondence to Dr. Willa A. Hsueh, University of Southern California, School of Medicine, 2025 Zonal Avenue, Los Angeles, CA 90033.

Received for publication 1 August 1988 and in revised form 3 January 1989.

J. Clin. Invest.

(C) The American Society for Clinical Investigation, Inc.

$0021-9738 / 89 / 06 / 2085 / 08 \quad \$ 2.00$

Volume 83, June 1989, 2085-2092 fusates of whole organ cultures have been compared with renin immunohistochemical studies, renin has variably been found not only in chorion and decidua but also in neighboring tissues such as uterine myometrium and amnion (7, summarized in reference 8 ). Thus, the objective of the present investigation was to define more precisely the source of renin biosynthesis in the uterus, fetal membranes, and placenta, and to characterize renin produced by human uterine lining. In particular, decidua was sampled in the absence of chorion from ectopic pregnancies, and chorion without decidua contamination was sampled from the basal plate and from common chorion between opposing amniotic membranes in dichorionic-diamniotic twin pregnancies. Our results demonstrate that $(a)$ both endometrium and decidua contain and secrete renin; $(b)$ the major form of renin secreted by human decidual cells in culture is prorenin; and $(c)$ decidua and endometrium express the renin message while chorion not anatomically in contact with decidua (i.e., basal plate chorion and intertwin chorion) demonstrates no detectable expression of the renin gene. In addition, myometrium, placental villi, and amnion also demonstrate no detectable renin gene expression. We conclude that human decidua is a major source of prorenin in the uteroplacental unit. In previous studies the demonstration of renin production by cultured fetal chorion was probably the result of contamination by maternal decidua. These results will be important in elucidating the role of local tissue renin production in human pregnancy.

\section{Methods}

Measurements. Active renin concentration was determined by RIA of angiotensin I (AI) ${ }^{1}$ generated by incubation with excess semipurified sheep angiotensinogen, final concentration $1 \mu \mathrm{M}$, at $\mathrm{pH} 7.4,37^{\circ} \mathrm{C}$ for 10-30 $\mathrm{min}$ in the presence of $5 \mathrm{mM}$ EDTA, $16 \mathrm{mM}$ 1,2-dimercaptopropane, and $3.4 \mathrm{mM} 8$-hydroxyquinoline (9). In this assay, generation of $1.2 \times 10^{5} \mathrm{ng} \mathrm{AI} / \mathrm{ml}$ per $\mathrm{h}$ is equal to 1 Goldblatt unit (GU) of renin as determined against Medical Research Council renal renin standard (68-356) from the National Institute of Biological Standards and Controls, Holly Hill, London. Total renin was measured after acid dialysis against $0.5 \mathrm{M}$ glycine buffer, $\mathrm{pH} 3.3$, at $4^{\circ} \mathrm{C}$ and titrated to $\mathrm{pH} 7.1$ with $1.0 \mathrm{M}$ phosphate buffer, $\mathrm{pH}$ 8.0. After this procedure plasma renin is totally activated, but activation is reversible. Therefore, samples were incubated with sheep angiotensinogen for five time periods between 0 and $0.5 \mathrm{~h}$ at $\mathrm{pH} 7.5$, and the slope of $\mathrm{AI}$ concentration vs. time was determined by linear regression analysis, with an $r$ value of 0.96 being acceptable (10). Prorenin concentration is the difference between total and active renin.

Tissue collection. Tissues were obtained after written informed consent. Human endometrium was collected by curetting the uterus of seven healthy premenopausal women undergoing abdominal hysterectomy for uterine leiomyomata or vaginal hysterectomy for pelvic relaxation. Their mean age was $36 \pm 4$ yr. Pregnancy tissue was ob-

1. Abbreviations used in this paper: $\mathrm{AI}$, angiotensin $\mathrm{I}$; $\mathrm{C}$-section, cesarean section; $\mathrm{CHO}$, Chinese hamster ovary; GU, Goldblatt unit. 
tained from healthy pregnant women undergoing cesarean section (Csection) for dysfunctional labor or fetal distress at 36-42 wk gestation. Pregnancy tissue was also obtained from two women who required cesarean hysterectomy for postpartum hemorrhage. The mean age of the pregnant women was $32 \pm 2$ yr. The different tissues collected are depicted in Fig. $1 A$. Decidua, placenta, and fetal membranes were obtained from a total of 12 pregnant women with a single fetus and 6 pregnant women with twin fetuses. Human decidua was collected by curettage of the uterine lining after removal of the placenta and fetal membrane fragments after delivery of the placenta: $(a)$ chorion laeve, lining the uterus, was separated from amnion by careful peeling; $(b)$ basal plate chorion was peeled as a visibly separate layer from the fetal side of the placental surface with care taken to avoid blood vessels; and $(c)$ in the case of twin pregnancies, intertwin chorion was carefully peeled away from the two layers of amnion between each fetus. Basal plate chorion and intertwin chorion were used to obtain samples of chorion not in contact with decidua. Histologic examination demonstrated that basal plate chorion and intertwin chorion contained viable trophoblastic cells and no maternal decidua. In contrast, chorion laeve had large amounts of decidua attached to the membrane (Fig. $1 \mathrm{~B}$ ). Placental villi were obtained as placental tissue separate from the fetal membranes. Myometrium was dissected from the uterine fundus of patients requiring cesarean hysterectomy. It represented the middle portion of the uterine wall and was carefully excised to avoid decidual and serosal contamination. Human decidua was also obtained from patients with ectopic pregnancy at 6-10 wk gestation during curettage of the uterus. Renal cortex was obtained at the time of surgery from normotensive patients requiring nephrectomy for renal tumors; a macroscopically normal area of kidney as determined by pathological examination was used. Tissues were either used immediately or immediately frozen at $-70^{\circ} \mathrm{C}$.

Homogenization. $1 \mathrm{~g}$ of tissue was homogenized in 2 vol buffer $(5$ mM Na phosphate, $\mathrm{pH} 7.1$, containing $10 \mathrm{mM}$ EDTA, 2 mM PMSF, 8-hydroxyquinoline, aprotinin, 20,000 kallikrein inhibitor units/ 1 and $20 \mathrm{mM}$ benzamidine) with a Tissumizer (Tekmar Co., Cincinnati, $\mathrm{OH}$ ) at $4^{\circ} \mathrm{C}$ as previously reported for human kidney tissue (9). After centrifugation of the homogenate at $10,000 \mathrm{rpm}$ for $30 \mathrm{~min}$, the supernate was assayed for renin. Tissue homogenate renin levels were expressed as nanograms AI generated/hour per gram wet weight of tissue. Renin in endometrium vs. decidua was compared by Wilcoxon rank sum analysis using the University of Southern California Clinical Research Center CLINFO system. Studies comparing tissue renin from C-section vs. twin pregnancy were performed using the paired $t$ test.

$R N A$ extraction and hybridization. Tissues obtained at the time of surgery were immediately placed on dry ice and stored in $4 \mathrm{M}$ guanidinium isothiocyanate. RNA was isolated using two techniques. One was a modification of the technique of Chirgwin et al. (11). All solutions were treated with $0.1 \%$ diethylpyrocarbonate to remove RNAase. Tissue was homogenized in 9 vol of guanidinium isothiocyanate $(4 \mathrm{M})$, saturated with cesium chloride ( $\mathrm{CsCl} ; 1 \mathrm{~g} / 2.5 \mathrm{ml}$ ), and layered onto 5.7 $\mathrm{M} \mathrm{CsCl}$. Ultracentrifugation was carried out at $30,000 \mathrm{rpm}$ at $20^{\circ} \mathrm{C}$ for $16 \mathrm{~h}$ in an SW40 rotor (Beckman Instruments, Inc., Palo Alto, CA). The pellet of total RNA that sedimented to the bottom of the tube was resuspended in Tris buffer, extracted with phenol and chloroformisoamyl alcohol, and precipitated in ethanol. A second method of RNA extraction was that of Chomczynski et al. (12). $1 \mathrm{~g}$ of tissue was homogenized in $10 \mathrm{ml}$ of a denaturing solution containing $4 \mathrm{M}$ guani-

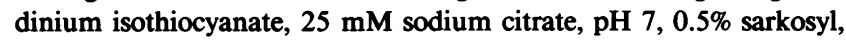
and $0.1 \mathrm{M}$ 2-mercaptoethanol. This tissue solution was then extracted twice with $2 \mathrm{M}$ sodium acetate, $\mathrm{pH} 4.0$, phenol, and chloroform-isoamyl alcohol. RNA present in the aqueous phase resulting from centrifugation was precipitated with isopropanol. Total RNA was quantitated by ultraviolet absorbance measurements at $260 \mathrm{~nm}$ using a photometer (Roy V Spectronic 1201; Milton Roy Spectronic, Rochester, NY). RNA was stored in ethanol at $-70^{\circ} \mathrm{C}$.

Northern blot analysis. Total cellular RNA (20 $\mu \mathrm{g} / \mathrm{lane})$ was electrophoresed on $1.0 \%$ agarose under denaturing conditions according to the method of Lehrach et al. (13) and transferred to nylon membranes (MSI Magnagraph; Fisher Scientific Co., Pittsburgh, PA). RNA was crosslinked to the membrane by ultraviolet irradiation and hybridized to specific probes using the procedure of Church and Gilbert (14). Hybridization was carried out for $72 \mathrm{~h}$ at $42^{\circ} \mathrm{C}$. After hybridization, membranes underwent three 15 -min washes. The first was done at room temperature in $2 \times$ standard saline citrate $(0.03 \mathrm{M}$ sodium chloride, $0.003 \mathrm{M}$ sodium citrate), $1 \% \mathrm{SDS}$. The second was performed at room temperature in $0.2 \times$ standard saline citrate, $1.0 \%$ SDS. The final wash was done at $55^{\circ} \mathrm{C}$ in the latter solution. Membranes were then subjected to autoradiography for $24-48 \mathrm{~h}$ at $-70^{\circ} \mathrm{C}$.

Source and labeling of DNA probes. A $600-\mathrm{bp}$ cDNA probe of the carboxy terminus $\left(3^{\prime}\right)$ of intact human renin cDNA was kindly provided by Dr. Tim Reudelheuber (University of California, San Francisco). Mouse $\alpha$-skeletal actin cDNA (1,000 bp) was obtained from Dr. Amy Lee (University of Southern California Comprehensive Cancer Center). Probes were labeled with $\alpha-\left[{ }^{32} \mathrm{P}\right] \mathrm{d}$ CTP (ICN Radiochemicals, Irvine, $\mathrm{CA}$ ) to specific activities $>10^{8} / \mu \mathrm{g}$ by random priming as described by Feinberg and Vogelstein (15).

Culture. Decidua or endometrium was digested in $0.1 \%$ collagenase and $0.2 \%$ hyaluronidase in DME (Sigma Chemical Co., St. Louis, MO) for $3 \mathrm{~h}$ at $37^{\circ} \mathrm{C}$. Suspensions were centrifuged $\left(600 \mathrm{~g}, 28^{\circ} \mathrm{C}\right)$ for $5 \mathrm{~min}$ and cells were then dispersed in $0.9 \% \mathrm{NH}_{4} \mathrm{Cl}$ for $15 \mathrm{~min}$ at $37^{\circ} \mathrm{C}$ to cause hemolysis. Suspensions were again centrifuged and cells were washed twice in PBS. Cells were resuspended (DME $+10 \%$ newborn calf serum; Irvine Scientific, Santa Ana, CA), plated $\left(10^{5}\right.$ cells $\left./ \mathrm{ml}\right)$ in $35-\mathrm{mm}$ wells, and incubated at $37^{\circ} \mathrm{C}$ in $10 \% \mathrm{CO}_{2}, 90 \%$ air. Media were changed every 2-3 d and collected at each change for renin assay. Cells were then subjected to trypsin digestion and counted (Coulter Counter, model ZBI analyzer; Coulter Electronics Inc., Hialeah, FL). Trypan blue exclusion was used as an index of the viability of cells in culture. Immunostaining of the cultured cells using the avidin-biotin complex technique (16) with antibodies against vimentin, keratin, and Factor VIII was used to assess whether the cells were predominantly stromal, epithelial, or endothelial, respectively.

Renin characterization. Immunoblot analysis was performed as described (17). Renin from decidual culture media was compared with pure human renal renin (17) and recombinant prorenin (18). Recombinant prorenin was obtained from the culture media of Chinese hamster ovary $(\mathrm{CHO})$ cells transfected with the human renin gene and partially purified by ion exchange and Cibacron blue chromatographies (19). Rabbit antiserum developed against pure human renal renin (17) was used to detect immunoreactive forms of renin after Western blotting. Antiserum developed against the carboxy-terminal 12 amino acids of the prosegment of human prorenin was used to detect forms of renin with this propeptide attached $(18,20)$. Renin forms were immunoprecipitated after incubation of decidual culture media $\left(10^{-3} \mathrm{GU}\right)$ and recombinant prorenin $\left(10^{-3} \mathrm{GU}\right)$ with varying dilutions of the prosegment antibody or the human renal renin antibody for $24 \mathrm{~h}, \mathrm{pH} 7.5$, at $4^{\circ} \mathrm{C}$. Antigen-antibody complexes were precipitated with protein A Sepharose 4B (Pharmacia Fine Chemicals, Piscataway, NJ). Samples were centrifuged and the supernate assayed for active and total renin.

For $\left[{ }^{3} \mathrm{H}\right]$ leucine incorporation, cells in culture were incubated for 2 $\mathrm{h}$ in medium lacking leucine and then for $6 \mathrm{~h}$ in fresh medium containing $\left[{ }^{3} \mathrm{H}\right]$ leucine $(1 \mathrm{mCi} / \mathrm{ml} ; \mathrm{ICN}$ Biomedicals, Inc. (Costa Mesa, CA). Radiolabeled renin was isolated by immunoprecipitation and run on SDS gels that were subjected to autoradiography.

\section{Results}

\section{Renin in human decidua and endometrium}

Tissue homogenate. The supernate of both decidual and endometrial homogenates contained active and prorenin. However, the concentrations of active and total renin were higher in decidua than in endometrium when tissues were processed identically and measured in the same renin assay (Fig. 2). The 

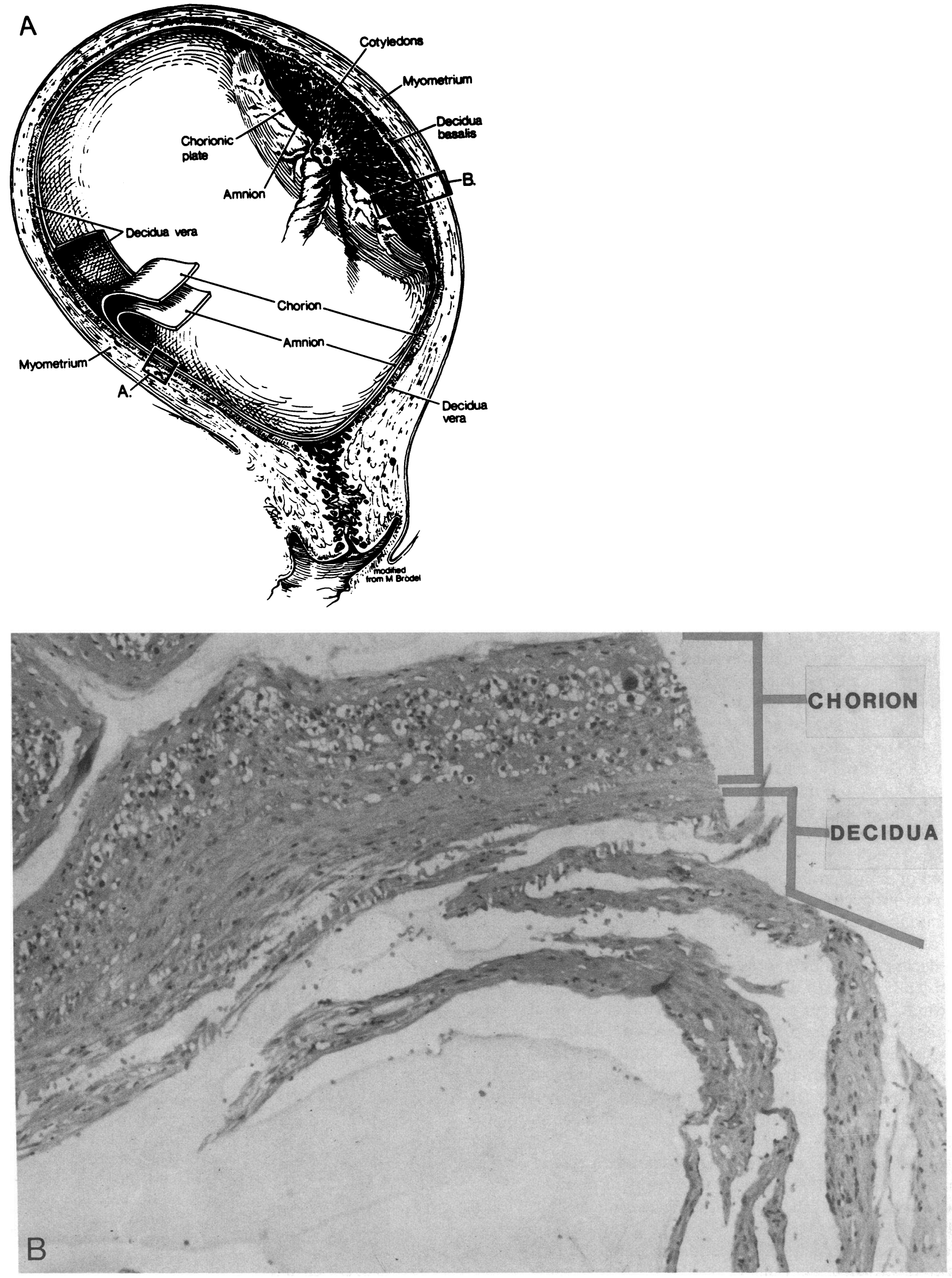

Figure 1. (A) Human uteroplacental unit. Chorion laeve (chorion) lies in direct contact with maternal decidua, whereas the basal chorion plate is separated from decidua by the intervening placental cotyledons (villi). (From Pritchard, J. A., P. C. McDonald, and N. F. Gant. 1985. Williams Obstetrics. Appleton-Century-Crofts, Norwalk, CT. 65-66, 98-108, with permission.) (B) Hematoxylin and eosin staining of human chorion laeve. Note the large amount of maternal decidua attached to chorion. 


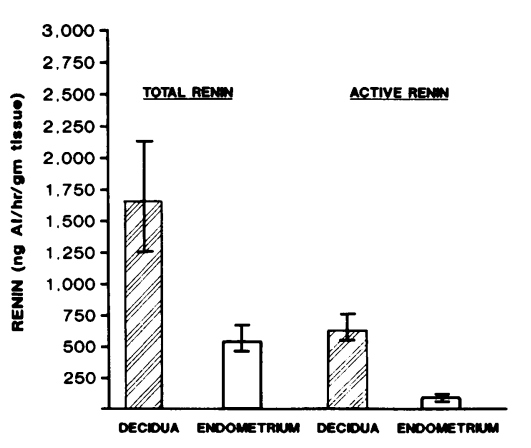

mean total renin concentration was $1,692 \pm 423 \mathrm{ng} \mathrm{AI} / \mathrm{h}$ per $\mathrm{g}$ (wet weight tissue) for decidua from five normal pregnant women and $544 \pm 85 \mathrm{ng} \mathrm{AI} / \mathrm{h}$ per $\mathrm{g}$ for endometrium from six premenopausal women $(P<0.01)$; active renin was 648 and $53 \mathrm{ng} \mathrm{Al} / \mathrm{ml}$ per h per $\mathrm{g}(P<0.01)$, respectively, and prorenin was $1,052 \pm 313$ and $486 \pm 88 \mathrm{ng} \mathrm{AI} / \mathrm{ml}$ per $\mathrm{h}$ per $\mathrm{g}(P=\mathrm{NS})$, respectively. In decidua, active renin contributed to $\sim 38 \%$ of the total renin, while in endometrium it contributed to $10 \%$ of the total.

Renin concentration in culture media. Decidua was cultured from four normal pregnant women requiring $\mathrm{C}$-section and three women with ectopic pregnancies. Endometrium was cultured from four nonpregnant women. Cultures of endometrium and decidua had a similar microscopic appearance. The majority of cells were elongated and spindly; these immunostained positively for vimentin. There were occasional clusters of crescent-shaped vacuolated cells, which immunostained positively for keratin. No cells had positive staining for Factor VIII. Thus, stroma appeared to represent the major cell type in the decidua and endometrial primary cultures, although areas ( $<10 \%$ of the total cells) of epithelial cells were present. From $4 \mathrm{~d}$ to up to $3 \mathrm{wk}$ of culture the major form of renin produced by decidua or endometrium was inactive prorenin. The pattern of renin production is illustrated in Fig. 3. Total renin secreted into the media by decidua or endometrium peaked at $\sim 2 \mathrm{wk}$ of culture. When expressed as total renin $/ 10^{4}$ cells, cultured decidua from both intrauterine and ectopic pregnancies consistently produced higher levels of total renin than did endometrium. Active renin constituted $\sim 10 \%$ of the total renin in the culture media of both decidua and endometrium. The time course of active renin production paralleled that of prorenin. After $2 \mathrm{wk}$ of culture, cell number continued to increase and cell morphology remained the same. Thus, neither of these factors contributed to the declining media renin levels after this time.

Characterization of renin produced by cultured decidua. Immunoblot analysis demonstrated that renin in decidual media crossreacted with the anti-human active renal renin antibody (Fig. 4) and had a mol wt of 47,000. The molecular weight was the same as that determined for recombinant prorenin (18). It was larger than that of pure active human renal renin which has a mol wt of 44,000 and also has 22,000 and 18,000 mol wt subunits (17).

The antibody directed against the prosegment of renin similarly precipitated renin in medium conditioned by either de-

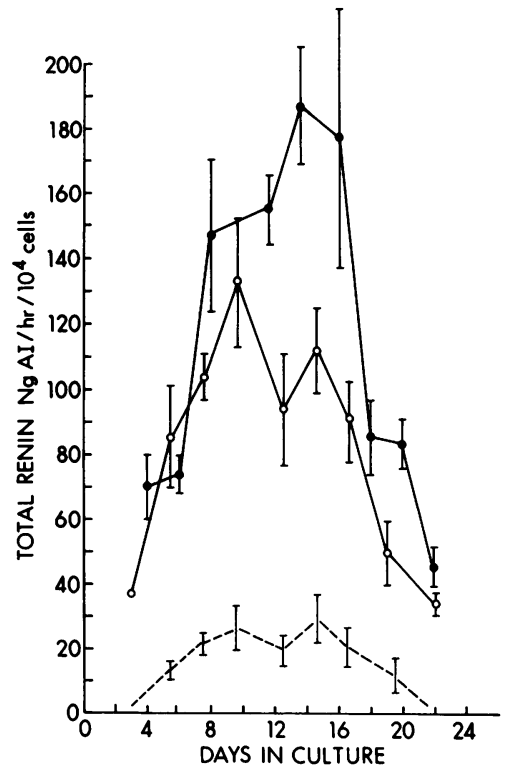

Figure 3. Total renin production by cultured human decidua cells from term pregnancy ( $n$ $=4)(0)$, from ectopic pregnancy $(n=3)(\bullet)$, and by cultured human endometrial cells $(n$ $=4)(---)$. Each symbol represents the mean and SEM of three wells from each patient assayed in duplicate. Total renin levels are similar in the media of decidua from term and ectopic pregnancy, but lower in media from endometrium.

cidua or $\mathrm{CHO}$ cells (Fig. 5). $50 \%$ of the renin was precipitated with $\sim 1 / 500$ dilution of the prosegment antibody. Active renin from decidua was not precipitated by this antibody. Renin from decidua or $\mathrm{CHO}$ cells also precipitated the antihuman renal renin antibody. 50\% inhibition occurred with a $\sim 1 / 2,000$ dilution of this antibody.

Immunoprecipitation of radiolabeled renin with antihuman renal renin antibody demonstrated that cultured decidual cells produced a single protein that crossreacted with the anti-human renin antibody. It had a mol wt of 47,000 , in agreement with data obtained by immunoblot analysis of unlabeled culture media.

\section{Localization of renin production in the uteroplacental unit}

Renin concentration in decidua vs. chorion. Total and active renin concentrations were measured in tissue homogenates of full-term decidua, chorion laeve, and basal plate chorion obtained from five women undergoing C-section (Fig. 6). In each patient the decidua and chorion laeve homogenates had similar levels of total renin, while the homogenate of basal plate chorion had significantly lower levels of total renin $(P<0.05$, paired $t$ test). The total renin concentration in the decidua homogenates in this group of patients was not significantly different from the group sampled in Fig. 1. In five other pa-

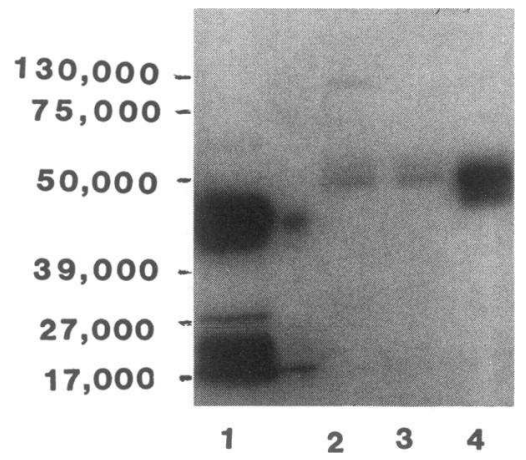

Figure 4. Immunoblot analysis of human decidua renin. Lane 1 is pure human renal renin with a mol wt of 44,000 , with 22,000 , and $18,000 \mathrm{~mol} \mathrm{wt} \mathrm{sub-}$ units. Lane 2 is culture media containing recombinant prorenin with a mol wt of 47,000 . Lane 3 is media of human decidua cells in culture. Lane 4 is purified recombinant prorenin. 


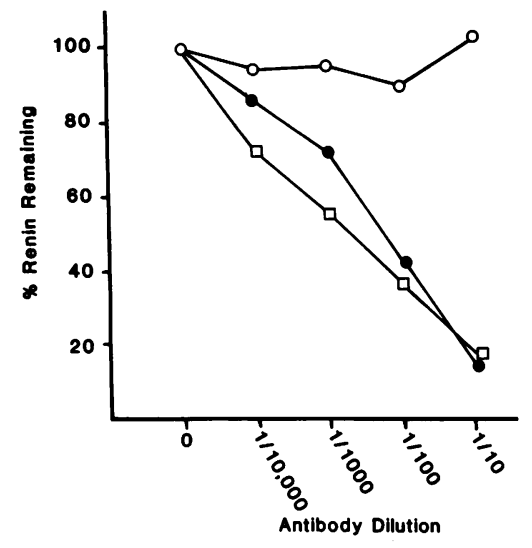

Figure 5. Inhibition of decidual (๑) and recombinant prorenin ( $\square$ ) by prosegment antibody. Both decidual and recombinant prorenin produced in culture were precipitated similarly by the prosegment antibody $(50 \%$ at a 1:500 antibody dilution), whereas active renin from decidual cultures (o) was unaffected.

tients with twin pregnancies similar levels of total renin were found in chorion laeve homogenates (Fig. 6). However, in these patients intertwin chorion levels of total renin were significantly lower $(P<0.01$, paired $t$ test $)$ than in chorion laeve. Active renin concentration in these tissues ranged from 30 to $40 \%$ of the total renin concentration in decidua and chorion laeve and 10 to $20 \%$ of the total renin in basal plate chorion and intertwin chorion. Histologic evaluation of all of these tissues demonstrated decidua was present in chorion laeve but not in basal plate chorion or intertwin chorion.

Northern blot analysis of uteroplacental tissues. Total RNA was extracted from decidua, chorion laeve, intertwin chorion, basal plate chorion, amnion, myometrium, and placental villi obtained from normal pregnant women. In addition, uterine lining without chorion was obtained from patients with ectopic pregnancies and from nonpregnant women. Total RNA extracted from human kidney cortex was used as a positive control. The total RNA yield ranged from 100 to $400 \mu \mathrm{g} / \mathrm{g}$ tissue (wet weight). The A260/A280 were similar in the various tissues, ranging from 1.7 to 1.9. Representative blots are shown in Fig. 7. Positive renin mRNA was defined as a single band at $1.5 \mathrm{~kb}$, which is the known size of human renin mRNA (21-24). Some RNA degradation is evidenced by tailing after the band but this did not interfere with the interpre-

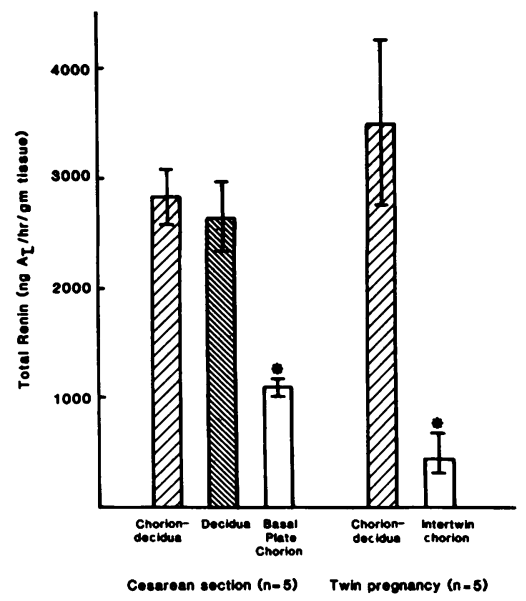

Figure 6. Total renin levels in decidua, chorion laeve (chorion-decidua), and basal plate chorion homogenates. All three samples were obtained from the same patients. Basal plate chorion had signifcantly lower total renin levels $(P<0.05)$. Chorion laeve (chorion-decidua) and intertwin chorion were obtained from a separate group of patients with twin pregnancies. Intertwin chorion total renin levels were significantly lower than chorion laeve $(P<0.01)$. tation of the results or constitute a positive result. Renin mRNA expression was detected in kidney, decidua, and chorion laeve from normal pregnant women, in decidua from women with ectopic pregnancy, and in endometrium. In contrast, renin mRNA expression was not detected in basal plate chorion or intertwin chorion. In addition, amnion, myometrium, and placental villi did not demonstrate detectable renin mRNA. Reprobing the same membrane with actin cDNA showed that the actin message was present in all lanes in approximately equal quantities (results not shown). Table I summarizes our results from tissues sampled from different patients.

\section{Discussion}

Investigation of gene expression is a powerful tool to identify tissue biosynthesis of proteins and to study their regulation. Detection of renin gene expression in the present study ultimately identified human decidua as a major source of renin in the uteroplacental unit. Previous studies have suggested a seemingly ubiquitous production of renin by uterine and placental tissues, leading to confusion regarding the source and physiologic role of tissue renin in pregnancy $(6,8,25,26)$. We examined renin gene expression in various tissues in the uteroplacental unit to address this issue. Particular attention was given to obtaining decidua without chorion (i.e., decidua from ectopic pregnancies) and conversely, chorion without decidua (i.e., intertwin and basal plate chorion [27]). Additionally, endometrium was studied since it represented the uterine lining in the nonpregnant state. In this study we demonstrated consistent renin gene expression in decidua from both intrauterine and ectopic pregnancies and in endometrium. Chorion laeve, shown histologically to contain decidua, also demonstrated renin gene expression. In contrast, renin mRNA was nondetectable in basal plate and intertwin chorion, as well as in amnion, placental villi, and myometrium. These findings indicate that decidua is a primary source of renin. This conclusion is supported by measurement of tissue renin content, demonstrating decidual content to be significantly greater than that of basal plate and intertwin chorion. This is further confirmed by demonstration of renin production by cultured decidual cells from both intrauterine and ectopic pregnancies.

This conclusion conflicts, in part, with previous reports; yet, several explanations may be offered. Tissue culture studies have described chorion laeve as a primary source of renin $(6,7$, 26). One report appropriately termed this tissue "choriodecidua," having noted the significant amount of decidua attached to chorion (7). Once chorion laeve is cultured, either chorionic, decidual, or both cell types could be responsible for renin produced. Since cultured decidua not in contact with chorion (i.e., from ectopic pregnancies) produces renin in quantities similar to cultured decidua from normal intrauterine pregnancies, decidual production of renin is independent of contact with the chorion in culture. Intertwin and basal plate chorion, which do not touch decidua, grow very poorly in culture (Shaw, K., Y. S. Do, and W. Hsueh, unpublished observations); furthermore, renin mRNA was not detected in either of these chorions. Taken together, these results suggest that renin produced by cultures of chorion laeve may be due to decidual contamination. Immunohistochemistry using a specific anti-renin antibody demonstrated positive staining in the 

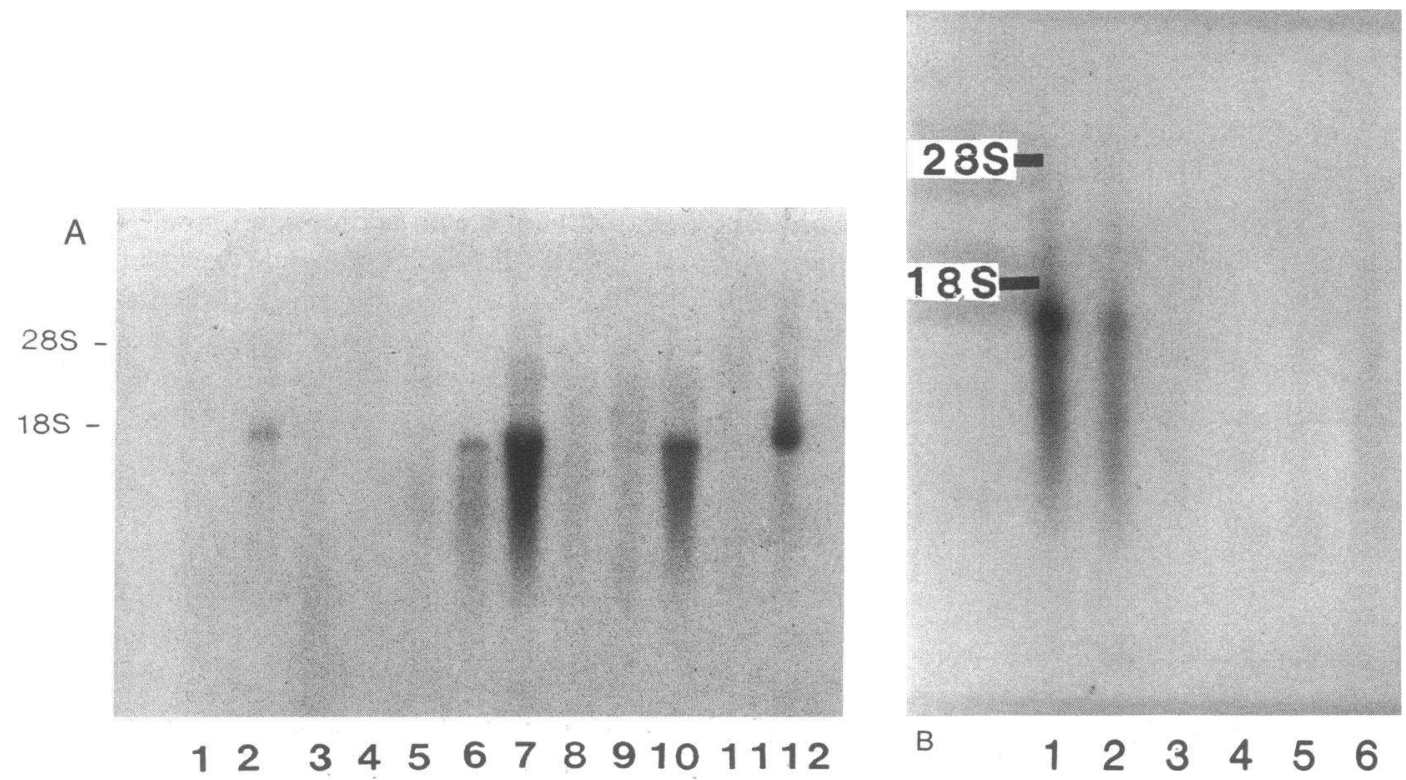

Figure 7. Human renin mRNA expression in uteroplacental unit. Total RNA (20 $\mu$ g/lane) was separated on a $1 \%$ agarose, transferred to nylon membranes, and then hybridized with a ${ }^{32}$ P-labeled human renin cDNA probe. $18 S$ and $28 S$ refer to ribosomal RNA species. $(A)$ Total RNA from endometrium (lane 2), placental villi (lane 3), myometrium (lane 4), amnion (lane 5), kidney (lane 6), dedidua (lane 7), myometrium (lane 8), villi (lane 9), chorion laeve (lane 10), basal plate chorion (lane 11), and ectopic decidua (lane 12). Lane 1 is a blank. (B) Total RNA was extracted from tissues obtained from a twin gestation. Decidua (lane 1 ), chorion laeve (lane 2), intertwin chorion (lane 3), basal plate chorion (lane 4), placental villi (lane 5), and amnion (lane 6).

cytotrophoblast layer of the chorion (25). Indeed, in our study we detected reninlike activity in homogenates of basal plate and intertwin chorion. These results do not necessarily indicate production of renin by these cells, but may reflect uptake of renin by the chorion. Amniotic fluid renin concentration is 10 times the plasma concentration $(1,28)$, and although contribution from the fetus may be important, amniotic fluid renin may be of decidual origin. Thus, transport across both chorion and amnion would be necessary. An analogous situation has been described for amniotic fluid prolactin that arises from maternal decidua $(29,30)$. The presence of renin in chorion without detectable renin mRNA expression supports the possibility of renin uptake by this tissue.

Table I. Tissue mRNA Expression

\begin{tabular}{llc}
\hline \multicolumn{1}{c}{ Tissue } & $n$ & $\begin{array}{r}\text { Renin } \\
\text { mRNA }\end{array}$ \\
\hline $\begin{array}{l}\text { Decidua } \\
\text { Intrauterine-pregnancy }\end{array}$ & 8 & \\
$\quad$ Ectopic pregnancy & 3 & + \\
Chorion & & \\
$\quad$ Laeve (choriodecidua) & 6 & + \\
Basal plate & 6 & - \\
Intertwin & 3 & - \\
Amnion & 6 & - \\
Villi & 6 & - \\
Myometrium & 4 & + \\
Endometrium & 3 & \\
\end{tabular}

Tissue renin gene expression: renin mRNA was consistently detected in uterine lining both in the nonpregnant (endometrium) and pregnant (decidua) state, as well as in chorion laeve. In other forms of chorion (basal plate and intertwin) renin mRNA was nondetectable, as was the case for amnion, placenta villi, and myometrium. Actin mRNA was detected in all tissues.
Myometrium has also been described as a source of renin, particularly in the rabbit $(31,32)$. However, immunohistochemical studies of human myometrium demonstrated renin staining only in small clusters of cells around blood vessels and not in smooth muscle cells (33). Human myometrial cells in culture were shown to produce renin, but only after 10-14 d of culture. This suggests that renin-producing cells constitute a small fraction of the initial cells cultured so that renin was detected only after these cells multiplied. Alternatively, as suggested by one author (26), renin production by cultured myometrial cells may be repressed in vivo and may represent an in vitro phenomenon. These data are consistent with our finding of no detectable renin mRNA in human myometrium.

Tritiated leucine incorporation in cultured decidua confirmed translation of renin mRNA. Immunoprecipitation and gel electrophoresis of the ${ }^{3} \mathrm{H}$-labeled proteins demonstrated a single renin band with a mol wt of 47,000 , which was confirmed by immunoblot analysis. Precipitation with an antibody generated against the carboxy-terminal third of the prosegment demonstrated that at least this portion of the prosegment was present on renin produced by cultured decidual cells. Thus, prorenin is the major form of renin produced by cultured human decidual cells. This system may be an effective tool in which to study renin production and processing in vitro, since isolated cultured human juxtaglomerular cells are not yet available. In fact, in cultured human cells found to produce renin, human decidual cells secrete about 6 -fold less renin than $\mathrm{CHO}$ cells transfected with the human renin gene (19), but secrete 100 -fold more renin than cultured human ovarian theca cells (34) and 5-fold more renin than primary cultures of an ovarian human renin-secreting tumor (35).

Endometrium and decidua both produce renin, yet our results suggest that pregnancy enhances renin production. The total renin in decidual homogenates was threefold greater than in similarly processed endometrial homogenates. When grown in culture under identical conditions, decidua produced three to four times the amount of prorenin per cell compared with 
endometrium. In pregnancy, the uterine lining hypertrophies and the cellular histology changes (36). After this decidualization process, hormonal or local hemodynamic alterations could enhance endometrial renin production either by increasing renin transcription or by enhancing the number of renin-producing cells. Further studies of the regulation of renin production by cultured decidual and endometrial cells will be important in assessing the role of pregnancy hormones on uterine renin production.

An additional observation is the discrepancy between the percent of the total renin that is active in tissue homogenates vs. cell culture. In our study active renin comprised $38 \%$ of the total renin in homogenized decidual tissue, compared with $10 \%$ for homogenized endometrium, while in culture the active percentage of both cell types was $10 \%$. Thawing and homogenization of tissue could conceivably inadvertently activate prorenin. However, a cocktail of protease inhibitors and rapid processing was used to prevent activation. Furthermore, decidua and endometrium were handled identically. Whether discrepancies between the percent active renin in decidual or endometrial homogenates are real or artifact remains to be determined. Similar findings were reported in a renin-secreting renal tumor (37) in which tumor tissue homogenates contained $72 \%$ active renin, while in cultured tumor cells the percent active renin decreased to as low as 3\% after 2 wk of culture. Hence, decidua may produce relatively larger quantities of active renin in vivo than when cultured in vitro.

The role of renin in human decidua and endometrium is unknown. Several potential roles exist, most of which are mediated by generation of angiotensin II. Thus, it will be important to determine $(a)$ if the large quantities of prorenin produced by decidua are activated and $(b)$ whether a complete renin-angiotensin system exists locally in the decidua and endometrium. Pure recombinant prorenin exists in equilibrium in an inactive and active form (38), so if relatively large quantities of prorenin were produced locally, a significant amount of active renin could be available to generate AI. Furthermore, a variety of enzymes can activate prorenin (39) so that activation could potentially occur extracellularly by enzymes released from tissues adjacent to decidua. Angiotensin II has been implicated in steroidogenesis, angiogenesis (40), growth (41), smooth muscle (vascular and uterine) contraction (42), and regulation of amniotic fluid volume and electrolytes (43). Further studies are needed to evaluate these potential roles and should include evaluation of the renin-angiotensin system in various pathologic states of pregnancy as well as investigations into factors regulating decidual production of renin.

\section{Acknowledgments}

This work was supported by grants from the American Heart Association, Florida Affiliate, and the National Institutes of Health (AM-30254). Dr. Hsueh has an NIH Research Center Development Award (AM-01035). Dr. Shaw has an NIH Fellowship (HL-07523). Dr. Anderson is a Research Fellow of the American Heart Association, Greater Los Angeles affiliate.

\section{References}

1. Hsueh, W. A., J. A. Luetscher, E. J. Carlson, G. Grislis, E. Fraze, and $A$. McHargue. 1982. Changes in active and inactive renin throughout pregnancy. J. Clin. Endocrinol. Metab. 54:1010-1015.
2. Sealey, J. E,, M. Wilson, A. A. Morganti, I. Zervoudakis, and J. H. Laragh. 1982. Changes in active and inactive renin throughout normal pregnancy. Clin. Exp. Hypertens. A4:2373-2384.

3. Itskovitz, J., and J. E. Sealey. 1987. Ovarian prorenin-renin-angiotensin system. Obstet. Gynecol. Surv. 42:545-551.

4. Derkx, F. H. M., A. T. Alberda, F. H. DeJong, F. H. Zeilmaker, J. W. Makovitz, and M. A. D. H. Schalekamp. 1987. Source of plasma prorenin in early and late pregnancy: observations in a patient with primary ovarian failure. J. Clin. Endocrinol. Metab. 65:349-353.

5. Brar, H. S., Y. S. Do, H. B. Tam, G. J. Valenzuela, R. D. Murray, L. D. Longo, M. L. Yonekura, and W. A. Hsueh. 1986. Uteroplacental unit as a source of elevated circulating prorenin levels in normal pregnancy. Am. J. Obstet. Gynecol. 155:1223-1226.

6. Acker, G. M., F. X. Galen, C. DeVaux, S. Foote, E. Papernik, A. Pesty, J. Menard, and P. Corvol. 1982. Human chorionic cells in primary culture: a model for renin biosynthesis. J. Clin. Endocrinol. Metab. 55:902-907.

7. Warren, A. Y., D. J. Craven, and E. M. Symonds. 1982. Production of active and inactive renin by cultured explants from human female genital tract. Br. J. Obstet. Gynaecol. 628-632.

8. Symonds, E. M. 1988. Renin and reproduction. Am. J. Obstet. Gynecol. 158:754-761.

9. Hsueh, W. A., E. J. Carlson, and V. Dzau. 1983. Characterization of inactive renin from human kidney and plasma. Evidence for a renal source of circulating inactive renin. J. Clin. Invest. 71:506-517.

10. Hsueh, W. A., E. J. Carlson, and M. Israel-Hagman. 1981. Mechanism of acid-activation of renin: role of kallikrein in renin activation. Hypertension. 3(Suppl. I):I-22, I-29.

11. Chirgwin, J. M., A. E. Pryzbyla, R. J. MacDonald, and W. J. Rutter. 1979. Isolation of biologically active ribonucleic acid from sources enriched in ribonuclease. Biochemistry. 5294-5299.

12. Chomczynski, P., and S. Nicoletta. 1987. Single-step method of RNH isolation by acid quanidinium thiocyanate-phenol-chloroform extraction. Anal. Biochem. 162:156-159.

13. Lehrach, M., D. Diamond, J. M. Wozmey, and H. Boedtker. 1977. RNA molecular weight determination by gel electrophoresis under denaturing conditions: a critical re-examination. J. Biochem. (Tokyo). 16:4743-4751.

14. Church, G. M., and W. Gilbert. 1984. Genomic sequencing. Proc. Natl. Acad. Sci. USA. 81:1991-1995.

15. Feinberg, A. P., and B. Vogelstein. 1983. A technique for radiolabeling DNA restriction endonuclease fragments to high specific activity. Anal. Biochem. 132:6-13.

16. Hsu, S. M., L. Raine, and H. Fanger. 1981. Use of avidin-biotin complex $(\mathrm{ABC})$ in immunoperoxidase techniques. J. Histochem. $\mathrm{Cy}$ tochem. 29:577-580.

17. Do, Y. S., T. Shinagawa, H. Tam, and W. Hsueh. 1987. Characterization of pure human renin: evidence for the subunit structure of human renal renin. J. Biol. Chem. 262:1037-1043.

18. Hsueh, W., Y. Do, T. Shinagawa, H. Tam, P. Ponte, and L. Fritz. Biochemical similarity of expressed human prorenin and native inactive renin. Hypertension. 8(Suppl. II):II-78-II-83.

19. Fritz, L. C., A. E. Arfsten, V. J. Dzau, S. A. Atlas, J. D. Baxter, J. C. Fiddes, J. Shine, C. L. Cofer, P. Kushner, and P. A. Ponta. 1986. Characterization of human prorenin expressed in mammalian cells from cloned cDNA. Proc. Natl. Acad. Sci. USA. 83:4114-4118.

20. Atlas, S. A., P. Christofalo, T. Hesson, J. E. Sealey, and L. C. Fritz. 1985. Immunological evidence that inactive renin is prorenin. Biochem. Biophys. Res. Commun. 132:1038-1045.

21. Imai, T., H. Miyazaki, S. Hirose, H. Hori, T. Hayashi, R. Kageyama, H. Ohkubo, S. Nakenishi, and K. Murakemi. 1983. Cloning and sequence analysis of cDNA for human renin precursor. Proc. Natl. Acad. Sci. USA. 80:7405-7409.

22. Hardman, J. A., Y. J. Hort, D. F. Catanzaro, J. T. Tellam, J. D. Baxter, B. J. Morris, and J. Shine. 1984. Primary structure of the human renin gene. DNA (NY). 3:457-468.

23. Hobart, P. M., M. Fogliano, B. A. O’Connor, I. M. Schaefer, 
and J. M. Chirgwin. 1984. Human renin gene: structure and sequence analysis. Proc. Natl. Acad. Sci. USA. 81:5026-5030.

24. Soubrier, F., J. J. Panthier, P. Corvol, and F. Rougeon. 1983. Molecular cloning and nucleotide sequence of a renin cDNA fragment. Nucleic Acids Res. 11:7181-7190.

25. Poisner, A. M., G. W. Wood, R. Poisner, and T. Inagami. 1981. Localization of renin in trophoblasts in human chorion laeve at term pregnancy. Endocrinology. 109:1150-1155.

26. Symonds, E. M., M. A. Stanley, and S. L. Skinner. 1968. Production of renin by in vitro cultures of human chorion and uterine muscle. Nature (Lond.). 217:1152-1154.

27. Lopez-Bernal, A., A. B. M. Anderson, D. M. Parry, and A. C. Turnbull. 1980. Evidence that fetal membranes are not involved in cortisol metabolism: study of dichorionic twin pregnancies. Am. J. Obstet. Gynecol. 138:1168-1172.

28. Lumbers, E. R. 1971. Activation of renin in amniotic fluid by low pH. Enzymologia. 40:329-333.

29. McCoshey, J. A., O. Y. Tagger, A. Wodzicki, and J. E. Tyson. 1982. Choriodecidual adhesion promotes decidual prolactin transport by human fetal membrane. Am. J. Physiol. 243:R552-R557.

30. Riddick, D. H., and I. A. Moslar. 1981. The transport of prolactin by human fetal membranes. J. Clin. Endocrinol. Metab. $52: 220-224$.

31. Ferris, T. F., P. Gorden, and P. J. Mulrow. Rabbit uterus as a source of renin. Am. J. Physiol. 212:698-702.

32. Dzau, V. J., D. Gonzalez, K. Ellison, S. Churchill, and N. Emmett. 1987. Characterization of purified rabbit uterine renin: influence of pregnancy on uterine inactive renin. Endocrinology. 120:358 364.
33. Johnson, J., I. R. Johnson, and J. E. Ronan. 1984: The site of renin in the human uterus. Histopathology (Oxf.). 8:273-278.

34. Do, Y. S., A. Sherrod, R. A. Lobo, R. J. Paulson, T. Shinagawa, S. Chen, S. Kjos, and W. A. Hsueh. 1988. Human ovarian theca cells are a source of renin. Proc. Natl. Acad. Sci. USA. 85:1957-1961.

35. Anderson, P. W., L. Macaulay, M. Koss, Y. S. Do, T. Shinagawa, and W. A. Hsueh. 1988. Morphology of renin processing by a human renin-secreting tumor. Clin. Res. 36:423. (Abstr.)

36. Pritchard, J. A., P. C. McDonald, and N. F. Gant. 1985. Williams Obstetrics. Appleton-Century-Crofts, Norwalk, CT. 65-66, 98-108.

37. Galen, F. X., M. Corvol, and C. Devaux. 1984. Renin biosynthesis by human tumoral juxtaglomerular cells. Evidence for a renin precursor. J. Clin. Invest. 73:1144-1155.

38. Heinrikson, R. L. 1988. The prorenin-renin interaction. Am Soc. Hyperten. Symp. Ser. 18.

39. Sealey, J. E., S. A. Atlas, and J. H. Laragh. 1980. Prorenin and other large molecular weight forms of renin. Endocrinol. Rev. 1:265291.

40. Fernandez, L. A., J. Twickler, and A. Mead. 1985. Neovascularization produced by angiotensin II. J. Lab. Clin. Med. 105:141-145.

41. Normal, J., B. Badie-Dezfooly, E. P. Nord, I. Kurtz, J. Schlosser, A. Chaudhari, and L. G. Fine. 1987. EGF-induced mitogenesis in proximal tubular cells: potentiation by angiotensin II. Am. J. Physiol. 253:F299-F309.

42. Re, R. N. 1984. Cellular biology of the renin-angiotensin systems. Arch. Intern. Med. 144:2037-2041.

43. Cooke, S. F., D. J. Craven, and E. M. Symonds. 1985. Osmolarity changes can enhance the release of renin from human chorion. Am. J. Obstet. Gynecol. 151:819-821. 